\title{
Social-cultural Practices of College Students: The Usage of Mobile Devices in the Classroom Environment
}

\author{
Ivana Maria Schnitman, Ed.D. \\ Federal University of Southern Bahia \\ Praça Joana Angélica, 250, São José \\ Teixeira de Freitas - BA, \\ Brazil, CEP: 45988-058
}

\begin{abstract}
One of the cultural signs of the contemporaneity is the intense relationship between youth and their mobile devices. In this context, mobile technologies, specially, notebooks and smart phones are used not just as a communication artifact, but as a space to mediate the face-to-face and virtual realities. This article intends to investigate the role those devices, considering their different uses have on college students learning experience within the classroom. The research examines in what sense student's behavior is changing by analyzing the relationship among different uses of mobile devices and student's learning habits inside the classroom.
\end{abstract}

Keywords: Cultural and social practices; Engagement, Self-regulation; Mobile technology

\section{Introduction}

Even the non-use of a certain technology denounces different forms of appropriation and consumerism of that technology. Mobile devices, specifically smartphones, among all the social functions they might have, become the elected vehicle of communication exchange. Reports show that $80 \%$ of all people accessing the Internet will be using a mobile device (Brooks, 20016). At the university level, relations between students are being configured and reconfigured all the time based, among other things, on symbolic exchanges.

The technological development smartphones are going through is allowing students to perform multiple activities, such as: sending text messages, calling, chatting, opening documents, checking e-mails, browsing internet and downloading files in a very convenient way. Smartphone technology provides immense benefits for users as they access and disseminate information rapidly (ALSON \& MISAGAL, 2016).

The importance of mobile technology to college students is unquestionable. The ECAR Study of Undergraduate Students and Information Technology report of, 2016, revealed shows that over half of students (52\%) own each of the three major mobile technologies - a laptop, a tablet or a smartphone (BROOKS, 2016). According to Pearson Student Mobile Device Survey 2015, college students feel a strong need to be continuously connected to the internet - with most of them (57\%) feeling the need to be connected every day, when at school. Consequently, mobile technology figures prominently in the future of higher education, particularly in its integration into teaching and learning. (ROSSING et al., 2012) point out that mobile technology allows students to expand discussion and investigation beyond the walls of the classroom, enabling collaboration and creation by allowing the interaction with a larger range of content.

Considering the perspective that a smartphone acquired to the human being, one can not avoid to highlight the multiple function cell phones present and the transformations originated from its multimedia characteristic. Sending email and messages, reading news, listening music, and communicating in real time, serve as support to this new form of sociability. (PAMPANELLI, 2004)

The growth of mobile technology in colleges is a current trend, inspiring researchers to investigate the influences the use of this technology has on a classroom environment. The proposal of this study is to discuss the role mobile devices have for higher education students, more specifically, within the classroom environment. Understanding such process is very dense, involving a variety of aspects. Nevertheless, it is important to highlight that the diversity of higher ed contexts, as well as students' uses, habits and, actions toward mobile devices are in constant transformation. Therefore, this paper attempts to examine how the use of mobile devices is affecting college students learning habits inside the classroom. This research objective was to examine in what sense student's learning behavior is changing by analyzing the relationship among the role of mobile devices has inside the classroom and how it relates to student's learning habits. 


\section{Net Generation}

The generation who was born after 1979 has grown in an environment where digital media was part of their daily life routine. To the current youth, digital media communication devices are as familiar as their bodies. They are commonly called Net Geners, and they play, learn, communicate and work with those devices. (MARTINS, 2015). As a result of the intense use of digital technologies, Don Tapscott (1999) outlined eight changes in education:

1. From linear, to hypermedia learning.

2. From instruction, to discovery and construction.

3. From centered on the teacher, to be centered on the student.

4. From a generation that absorb and analyze, to a generation that navigate and synthesize.

5. From school, to lifelong learning.

6. From learning to all, to customized learning.

7. From learning as a torture, to learning as an entertainment.

8. From the teacher as a content delivery, to a helper.

9. From students' responsibility, to learning as a social activity. (TAPSCOTT, 1999)

Kaiser Family Foundation survey (2005), found that with children and teens unlimited technology access, the amount of time spend with entertainment media has dramatically risen on their daily lives. In a typical day, young people (8-18 year-olds), spendan average of 8 hours using entertainment media (more than 53 hours a week). So, compared to previous generations, individuals raised immersed on digital technology deal with information differently. They are not just acculturated by the use of technology, but saturated by it. (BARNES et al, 2007)

As a result of this unlimited access to digital technology, Net Geners developed a proper form of thinking, communicating, and learning (BROOKS, 2016). The ingrained habits of seeking and retrieving information from the Internet have also changed their learning behavior. As Net Geners became more assertive information seekers, influenced on how they approach learning in the classroom. Digital Age students express a need for more variety forms of communication, tend to have a more independent and autonomous learning style, require immediacy on responses, desire more active and engaged learning experiences and, get bored easily with traditional learning methods. These students make choices about what learning strategies work best for them. (BARNES et al, 2007).

Net generation individuals learn differently from their predecessors. They developed hypertext minds and the ability to summarize pieces of information from multiple sources. Among other differences, Net Geners have enhanced theirs:

- Ability to read visual images.

- Visual-spatial skills

- Inductive discovery

- Attentional deployment

- Fast response time (OBLINGER \& OBLINGER, 2005)

\section{Mobile Technology and College Experience}

College experience is not just about learning in the classroom. It is also about encountering new social situations and gaining new social skills. College students use digital technologies nearly as much for social communication, as for educational purposes. But, as they use the Internet to supplement their education, they also go online to enhance their social lives.

With the advance of mobile technology, mobile devices became an important part of college students' educational experience. They use mobile devices to communicate with professors and classmates, to research and to access class materials. For most college students, mobile devices are a functional tool, that has changed the way they interact with others and with information. One of the reasons the use of mobile technology is such an important part of the daily routine of college students could be, in part, explained by the fact they have grown up with computers. It is integrated into their daily communication habits and has become a technology as ordinary as the television (JONES, 2002).

According to Jones (2002), 74\% of college students use the internet four or more hours per week, while about $19 \%$ use it twelve or more hours per week. Compared to the time students reported spend studying, it is higher. $62 \%$ of students reported studying for classes no more than 7 hours per week, while only $14 \%$ reported studying 12 or more hours per week. (JONES, 2002)

Mobile technology is highly related to internet access, which is mainly used by college students to: $42 \%$ use it primarily to communicate socially, $10 \%$ use it primarily for entertainment and $72 \%$ say to use it for communication with friends. (JONES, 2002). 
According to Alson and Misagal (2015), studies found that students are spending more time texting and, consequently, not paying attention to the class lecture. Students report that cell phones distract them from learning because texting disrupt their classroom concentration. Still as Jones (2002) suggests, college students are heavier users of online chat than those in the overall online population. A college student is twice as likely to use instant messaging on any given day compared to the average internet user.

In general, college students tend to consider more the positive aspects of mobile technology use in class. They see it as a tool, that enables them to engage with class content in a less traditional way, as skills or literacies they are expected to possess, and as something that excites or empowers them to learn. (BROOKS, 2016)

\section{The Study}

The objective of this study was to examine how the use of mobile devices is affecting college students learning habits inside the classroom. This study addressed the following research problem: One of the cultural sign of the contemporaneity is the intense relationship between youth and their mobile devices. In this context, mobile technologies, specially, notebooks and smart phones are used not just as a communication artifact, but also as a space to mediate the face-to-face and virtual realities. The research question that guided this study was: Based on the use mobile devices inside the classroom is posing, how students' behavior is changing towards their learning habits.

\subsection{Participants}

Considering the exploratory nature of this research and the depth intended to reach, was necessary that the study concentrates around a small group of students. For their selection were established the following criteria:

a) Subjects' age should range between 18 to 25 years old.

b) In order to be able to apprehend the effect of the use mobile devices in the learning habits inside the classroom, participants should use it extensively. Therefore, participants should have been bringing their own smartphone and/or notebook to the university for at least, one year.

c) To avoid that differences of financial status interfere, like access of more sophisticated devices - last generation of smartphones - and on the frequency of their use, subjects should belong to the same social and economic status.

There were no restrictions about gender or race. Based on those criteria and also taking into consideration the knowledge the researcher had of student's behavior towards the usage of mobile devices in class, subject was selected. In order to preserve their anonymity, all the participants received a fictitious name.

The sample was composed by 11 students from a small size public university. Participants were almost equally divided by gender - 6 males and 5 females, and the age distribution of the sample varied from 18 to 23 years old.

\section{Methodology}

To examine the phenomena, the study used a qualitative approach, focusing primarily on data collected in semistructured interviews. Basically, four questions were asked:

1. What do you use a smartphone and/or a laptop during class for (chat, read news, random navigation, research about the class content ...)?

2. How do you consider your concentration in the class content stays, while using those devices? Do you consider that those artifacts distract you from what is been learned in class?

3. What do you think about the way you use those devices (dependency, compulsion)?

4. How would you feel if a teacher asks you to do not use those devices during class?

\subsection{Data Gathering and analyzes}

Data was collected in a period of one week, at a small size public Brazilian University. For logistic purposes, interviews were conducted in group where participants were divided in 2 groups. Data analysis and interpretation was completed over the next six months of the same year. Student's individual responses to the interview's questions were recorded and transcribed. Following Creswells (2003) description of strategies encouraged to ensure the qualitative study's rigor and credibility, investigator reviewed the interview responses and generated a preliminary coding rubric to categorize recurring themes in the data. Researcher then looked for negative or discrepant information to clarify any bias, and modify the themes. Then reviewed the preliminary common themes and the current and past studies conducted on student behavior toward technology use in classroom and other research reports.

All interviews were completely transcribed and an analyzes of discourse was conducted. This analysis was accomplished in two steps. On the first step, comparisons inter-subject responses were conducted. For that matter, all subject's responses to each one of the questions were gathered. This procedure that allowed to have a panoramic view of the all responses, to each one of the questions. 
The recurrent responses were then analyzed, indicating the first main patterns that emerged from the group as a set. On the second step, analyzes intra-subjects, all responses of each one of the subjects were analyzed, in order to find possible conflicts of opinions, inconsistencies and contradictions between the all the responses of one same subject. Based on the insight provided by this step, researcher returned to the first step and conducted another analysis to all subjects' responses, to each one of questions. This cycle was repeated as many times as needed, and made possible to deepen the knowledge of the collected material, detecting what was not said, the subtleties, and many other aspects the study aimed to identify.

Based on that analysis, five major themes emerged from students' responses to the interview questions. Each theme featured different aspects of mobile technology usage in the classroom. The themes included:

1. Uses: Immediacy, Access and availability of information

2. Engagement

3. Multitasking

4. Dependency

5. Self-Regulation

\section{Results}

Using the discourse analysis method (GEE, 2011), this section provides evidencesfrom student's responsesto illustrate and support the findings of each theme.

\subsection{Uses, Immediacy, access and availability of information}

In many classroom activities, often, students are required to use the internet browser or web-based learning environments, such as Moodle, to locate resources or to find content. Student's responses featured both, positive and negative aspects towards the availability of information that mobile technology affords. Students responded positively to the ability to expand their search for information beyond the classroom walls.

"The computer is a necessity. I have to bring itbecause of the archives and materials. In our university context, we do not have easy access to books, and teachers send all the material that we will use in the classroom via online. So, if we do not bring the computer, we will be lost in class without the material. "(S2)

"When we are discussing or debating something that is of my interest, I have, sometimes, to enrich the debate, bringing elements and information that might not be occurring within the debate. So, I bring external information that might help me to reflect and position myself in the classroom. When I do not have a personal interest on that theme, it ends up happening a dispersion." (S1)

"Many times, I realize that the teacher sometimes takes 15, 30 minutes transmitting something, trying to convey something that I can understand and apprehend with just only one paragraph of reading. And some teachers have a deficit of bringing differentiated resources, such as, photographs and videos. So, while the teacher is giving the content and the syllabus was not given previously, I follow thecontent with the computer in the classroom, or at the cellphone too, and I can capture much better and be part of the discussion because I can consult other ideas, besides the one the teacher brought to the classroom. This enriches greatly my learning, because it brings another sensory form, besides the teacher's voice. I can also read and write." (S5)

Advocates of in-class mobile technology use argue that note taking may be more efficient on laptops and that students may find it easier to convert typed notes than hand-written notes into outlines. A related argument is that taking notes on a laptop tends to be faster and neater than handwriting those same notes. As can be seen by the student's responses, this aspect of usage is important.

"If I turn on the computer and focus only on taking notes of what is going on during class, I do not distract myself and I can still write down a lot, more than I would in the computer, for the sake of speed, understand? So, it distracts, but for me it depends on the use, it depends if I am accessing the internet or not. If I use it to access the internet, I get distracted. If I use it just for me to write down what is happening in class, I pay a lot of attention in class." (S11)

"For class notes, I usually use the computer. I like to make class notes in the computer. But, there is also the question of looking for things related to class." (S7)

However, students also reported downsides to easy information access and availability. Perhaps, the biggest drawn back relates to student's access to distractions, such as: social networking, email, and games. Participants admitted to access WhatsApp and Facebook rather to participate in classroom.

"But, in a way, it distracts, it distracts a lot. As much as it is to look for something related to the class, we end up, clicking on several other things and end up scattering there. You look beyond what it is. It is difficult to know when to stop looking." (S7) 
"I use cellphone mainly for WhatsApp or Instagram. The computer I use more for class content, to make notes, such as a notebook, to extract something out of class or to see random things. I spend a great part of the class looking at random things. "'(S4)

The utilitarian aspect of the internet access was also present. When the virtual world presents more advantages than the real world, mobile technology is an option to use the time in a more profitable way.

"Whenever you feel you will do something more profitable in the virtual world than in the real world. Because sometimes you are in a classroom, and you know that you will not going to understanding a thing, that you will not going to take anything with you, then why waste your time looking at the teacher's face if you can do something that, even if it will not add something, at least you like to do, get it?" (S11)

"If it is of my interest, the technological use impacts me positively. If it is not of my interest, it impacts negatively, because I might not be learning something that I do not know and is being discussed in the classroom. But I also understand that learning is not restricted to the classroom. So, not being present in the classroom does not mean I am not learning something else using technology. I may be reading another related subject, or building what I have already thought, or something like that. I have this distinction, that I learn both inside and outside the classroom. But eventually, the technological use in a couple of moments also impairs teaching-learning, as well as enriches it. Depends a lot on the situation." (S1)

\subsection{Attention/Multitasking}

Participants see multitasking as a tool that empowers them to seize control over their learning experience. One of the ways in which multitask improves student's levels of efficacy is utilitarian. All students agreed that mobile technology enables them to easily communicate, research content, and browse any other interest they might have at the class moment.

"As at the university, we have to do a lot of things at the same time, and eventually, when I find myself in the middle of those debates that I am not interested, I keep doing pending activities, such as: research, tabulate data, write an article or something like that." (S1)

Although students can learn in the presence of distractions, mobile phones and laptops provide distractions that demand more attention. Therefore, those technologies have the potential to reduce the cognitive resources available for in-class learning. (GINGERICH \& LINEWEAVER, 2018)Students found it hard to pay attention to class while they were using mobile devices.

"I think it distracts. That is why sometimes I prefer do not even bring the computer. In fact, I do not even use a computer. My problem is the cellphone. But I believe it really distracts because when the cell vibrates you get yourself distracted, like, you do not take class notes. So, yes, it distracts me." (S10)

"Well, I guess even if I did not consider a computer as a way of distraction, I would end up distracting myself with something else. Because I have, depending on the dynamics of the class, difficulty to concentrate on what is happening, regardless of whether I am interested or not. Sometimes, I look around and I get something to doodle. It is as if the mind starts slowly with something else. Then, I do think it is not the device's fault. It is a necessity. I do not know if it would be mental. I do not know exactly how to define this need. But it would be a necessity to wind down during class time." (S9)

"If you are in a chat app, you do not only talk to one person. You talk to three, four, or two groups, all at the same time, and still have an interpersonal interaction. Because today, it is common to invite people over and everyone be talking to each other and with their cellphones open. As well as to exchange information, talk and maintain affective relationships in the classroom. Sometimes the teacher is applying the content in the classroom using cool tools with great dynamics. But also, there are other important things happening. The important moment Brazil is going through. So, I give myself this liberty and I do not lose it." (S5)

The off-task mobile devices technology usage may be particularly detrimental to student learning success. Gingerich and Lineweaver (2018) show that even when students applied mobile technology toward classroom-related activities, there are no evidence that support their beliefs that mobile devices aided their learning. Researchers have shown that the length of web browsing sessions during class correlates negatively with overall course performance. (GINGERICH \& LINEWEAVER, 2018)

"When I do not have a personal interest on that theme, it ends up happening a dispersion. I often neglect to pay attention to class and end up paying attention to whatever I am doing or reading. As at the university, we have to do a lot of things at the same time, and eventually, when I find myself in the middle of those debates that I am not interested, I keep doing other activities, such as: research, tabulate data, write an article or something like that." (S1) 


\subsection{Engagement}

The usage of mobile phones in classroom settings is associated with off-task learning behavior in the classroom and how negatively it affects students' ability to learn new material.

"When the teacher is transmitting the content and I already understood what he meant, that is the moment I get distracted with the computer. I start doing random things in the computer but I can rapidly go back and do not lose the line of thought, because I had already understood what the teacher was talking about before. Although, if it is something that I am still picking up and I couldn't understand, and in that time I was at the computer reading something else, I get lost when I come back to the content. Then, I have to try, from the beginning, to understand where he stopped, so I can situate myself." (S3)

As stated by student's responses, the magnitude of interruptions posed by texting during class appears to depend on several factors. Students tend to underestimate their off-task technology use in classrooms, as they view their technology use as less disruptive as it really is.

"It depends a lot on what I'm using the device. If it is a quick check, there will be no time to get distracted. Now, if I am talking to someone about a problem that has happened, I will really go into another world there and I will not be able to even hear what is being said." (S7)

"It depends of what you are doing parallel to the lesson. For example, the chat, depending on the conversation, does not take too much of your attention from answering something. But, if you are talking something about $X$, and you are reading something about $Y$, then you will get confused. Something is going to be missed. But, in general, I particularly, am able to cope well with this. I can pay attention to, at least, two things." (S6)

"I might even manage to pay attention to the lesson, check my cellphone and computer simultaneously, most part of the lesson. But sometimes, we get lost on the way. Sometimes, there is something important that I want to learn, the teacher talks and I can link. Then I will stop and pay attention. But then, I come back and I keep on trying again, to assimilate the two things. But I can be doing one thing on the computer and another on my cellphone, and stay like that, most part of the lesson, because I have a little anxiety disorder. Because you might even be active, but I need to stay on the computer, typing, trying to read something. I come back, and try to do something else on the computer. I spend most of my time doing things, several things at the same time. But I know how to do those various things at the same time." (S4)

Students claim to get off-task using mobile devices when class is boring. They look on the virtual world, whatever they seem to not be finding in the real one.

"If the class is not very interesting, you are really going to look for something online to immerse yourself on, to focus on the cellphone, since what is happening does not interest you. But, it may happen that the class is interesting to you, but you go online fast, just to see something." (S7)

"Not always. It may be that ... It can, in fact, be a refuge. When you are bored in class or whatever you are doing, then you will take a refuge in the computer or in cellphone." (S4)

\subsection{Dependency}

Mobile addiction is a new problem, emerging from the heavy use individuals are given to mobile technology, specially to the cell phone. Dependency and other sociability issues are threatening the way young people relate to this artifact. Students' responses relate to this issue in several forms.

"There is the device dependency issue. I wanted to be less dependent. Not that I am addicted. No way. But, sometimes it is something that escapes to the understanding, because you know that there is nothing there, but you go and look. You have just opened the Facebook page, did not receive any notification, but you open and look again. It's a compulsion." (S2)

"Our society, the children and our generation are the cyberborg, right? Consider the cellphone as part of yourself. Today, in our society, to not have WhatsApp or any other social networks is, sometimes, inadmissible. I do check my WhatsApp frequently and the girls who live with me criticize me a lot. They say: I will send you a letter, because you do not look at your messages. But even not looking too much, I know I am extremely addicted and I use the cellphone as a part of me." (S3)

"Compulsion and anxiety are becoming common behaviors being associated with a technology heavy use. Student's responses show that connection.If it is a question of the person's motivation. It really becomes almost a compulsion. You already have the device in front of you open, with internet access at the university. So, one thing leads to another." (S9)

"I think I can learn a lot more when I am using these features, and I can even use my cellphone in my favor, as a distraction, without having to talk to my classmates and disrupt the class. So, if I do not have any device (neither computer, nor cellphone), I am going to be extremely anxious to leave class to pick it up." (S3) 
"I think anxiety affects most of the students. It is a counterweight: it is okay if you do not use the computer in class or even, use less the cellphone. But you can not forbid its use. Stay for two hours without accessing the cellphone generates anxiety." (S2)

Responses provide an important clue to understand the role a cellphone plays on the interviewers. If the absence of it leaves them disoriented, insecure and lonely, to have it close generates a sensation of security,of being accompanied. In fact, the comfort aspect explicitly appears in several responses from the interview.

"Because through the cellular, I can have countless interactions and sometimes even urgent ones, that I do not want to share neither with the class, nor with the teacher. And when that is taken into consideration, it becomes a question of delegitimization." (S5)

\subsection{Self-Regulation}

"Although students seemed to be aware that texting could interfere with their learning, they also believed they could control their attention spam by being able to multitask and self-monitor their focus between the lecture and the texting. The only thing is that you have the problem of seeing random things. For example, talk to someone on WhatsApp, on Facebook. But, in my case, this use does not overlap the lesson. The class continues as something more important that those random activities." (S2)

"I can not deny that there are several other tabs opened and that they also have something personal, like a social network. But I can adapt and use everything at the same time." (S5)

"Particularly speaking, it never happened to me, that a teacher asked me not to use the equipment. Sometimes, you say: "Oh, people, let pay attention" or something like that. But it has never particularly, influenced me not to use the equipment because of these words." (S1)

"Because we are in college, we are all adults, capable. If we are here, we know that maybe here is our professional education future and we will take it very seriously. And, whenever a teacher invades student choice to use or not a cellphone, he has to understand that today, cellphones do not represent just a research tool. They are also, something intimate. It is the representation of something very singular of the person. He wants to determine that ... it a very authoritarian discipline act in a context, which I see, as modern. ”(S5)

\section{Discussion}

The current study aimed to examine, based on the use mobile devices inside the classroom, how student's learning behavior is changing.

Altogether, the interviews showed five major themes that emerged from student's responses. Each theme reflected different aspects of mobile technology usage in the classroom, such as: uses: immediacy, easy access and availability of information, engagement, multitasking, dependency and self-regulation.

According to Jones (2002), in general, college students are satisfied with the use of mobile technology towards their educational experience. The majority of college students (89\%) have a positive attitude toward the use of internet and its communication tools for academic purposes. Their internet habits split between academic and social uses, and they find it functional, for both reasons.

Moreover, it is important to point out that Net Geners are fast, whether it is related to the immediacy that a response is expected or with the speed at which they are used to receive information. They multitask, move quickly from one activity to another, sometimes performing them simultaneously. They have fast response times, whether playing a game or responding to a class question. (OBLINGER \& OBLINGER, 2005) However, they realize that the Web does not meet all their information needs and participant's responses prove this idea correct. Digital students are more likely to use the internet for research than the library because they are used to find the information from the Web and they believe on its accuracy. Net Geners's constant use of many different media formats simultaneously shows another unique characteristic of their learning style: Multitasking. Kaiser Family Foundation survey (2005) found, Net Geners use computers and the Internet, at the same time as video games, print media, music, television and the phone. However, they do not accept that they might have a lack of attention span. Instead, they argue that is the lack of time what compels them to multitask. (BARNES et al, 2007)

When Net Geners complain that a particular subject seems unnecessary, they may not be expressing a lack of interest. Rather, the range of activities demanding their time and attention lower their patience with lessons that do not directly apply to their expectation. Multitasking, Net Geners claim, simply helps them get everything done. Whatever the motivation, educators must contend with the fact that multitasking is a way of life for many of today's students.

(BARNES et al, 2007) 
Although they do not admit, the attention-grabbing effect of mobile phones in classrooms is affecting the way college students experience learning. According to Gingerich and Lineweaver (2018), regular multitask habits prompts people to be more distracted by irrelevant information, be less efficient at distinguishing relevant from irrelevant mental representations, and less effective switching to a new task without interference from the previous one.

Results from this study also provide support for the potential of disruption and distraction the usage of mobile devices in classroom by college students can poise to their leaning. Although students may believe they are just dividing their attention among multiple tasks, instead, at a cognitive level, they are rapidly shifting their attention between the tasks rather than completing them at the same time. (GINGERICH \& LINEWEAVER, 2018)

As Kuznekoff and Titsworth (2013) show, the effects of texting/posting on student learning outcomes arguing that texting can cause distractions that reflect on student learning. Because learning is a process, diminished capacity with any other resource can impact cognitive resources. Thus, in the case of texting/posting, student's attention can be divided, which can distract attention from the learning task.

The relationship between student's self-regulation and how they use mobile technology in class is a key aspect when analyzing metacognition and cognitive learning in the current days. Specifically, when higher rates of texting behavior are present, students tend to be less able to self-regulate their behaviors in ways that allow them to succeed on class content assessments. (KUZNEKOFF \& TITSWORTH, 2013)

Related to engagement, Net Geners crave interactivity. The rapid pace with which they like to receive information means they often choose not to pay attention if a class is not interactive, unengaging, or simply too slow. (OBLINGER \& OBLINGER, 2005) Digital students seek to interact with others, whether in their personal lives, online presence, or in class. The average mobile user checks their device 150 times a day. By analyzing the behavior of use of mobile artifacts by college students, another issue was raised on this study: the addiction. Flurry Analytics report shows that 49\% of heavy use associated to mobile addiction occurs on 18-24 years old. (KHALAFON, 2014)

Because they were born immersed on digital technology, it is not surprising that digital natives see a smartphone as an essential artifact. The connectiveness and interactivity, define the postmodernity logic, and attributes to this device an almost, mythic character. This has been originating a phenomenon classified as mobile addiction. Without these sociotechnical artifact, the immediate access to the social media gets lost. And the absence of this access can promote a feeling of exclusion and isolation, promoting a new form of solitude (NICOLACI-DA-COSTA, 2005).

Students need clear boundaries in relation to a proper use of mobile technology within the classroom. To explicit what would be considered a proper use of mobile technology in class might reduce the level of distraction. ECAR Study of Undergraduate Students and Information Technology report of 2016 states that when freshman students are informed, as soon as they enroll at the university, about the basic programs used in classroom, they are significantly less propense to get distracted by the technology. So, it is important, when freshman students enroll, to provide training on university basics programs and systems and to associate to this training to basic orientations about what would be an appropriate and reasonable use of technology, inside and outside the classroom - specially on concern to social media. (BROOKS, 2016) These types of actions might help reduce the levels of distraction in the classroom. Although block the use of social media on campus seems to be an easy and less expensive solution to avoid the distraction issue, this kind of approach, on the long term, is less efficient, despite the fact that it restrains academic freedom and puts the university in a position of censorship (ROSSING et al. 2012).

\section{Conclusions}

Bauman (2001) considers the cell phone a technology symbol of the compression space-time, being one of the marks of the "liquid modernity": Cell phones (invented to satisfy the need to must be constantly in touch), portable belongings or dischargeable - are the cultural objects of the instantaneity era. (BAUMAN, 2001)

On contemporaneity, the dissemination of mobile phones opened unprecedentedcommunication opportunities. The mobile aspect of the new media and its social use required from man to create new ways of interaction and of being together. (PAMPANELLI, 2004)

However, as Nicolaci-da-Costa (2004) points out, the changes mobile artifacts are causing in our daily life is not just about the sociability. To an individual level, changes on freedom, autonomy and privacy can be noticed as well. The centrality smart phones acquire in our daily lives is intimately related to the inclusion need, proper of the contemporaneity era, time marked by the instantaneity, mobility and virtuality, turning the use of a smart phone become a way of being part of the society itself (SILVA, 2007).

Considering the importance college students attribute to the personal use of a smart phone, it is important to comprehend how much they can represent on their educational experience. One of the big discussions the present educational model faces refers to the incorporation of online digital technologies in the classroom environment. 
If they are, in fact, diverting student's attention or contributing to their learning. But, more importantly, if mobile devices distract or collaborate with learning, is there something that can be done about it. Certainly, to limit or even prohibit its use in the classroom will not avoid students to continue searching for alternatives when facing a less attractive and motivating lesson.

Thus, to combine active learning pedagogical approaches with the intentional use of digital technology towards the learning process could improve student's engagement. $63 \%$ of college students use mobile devices inside the classroom and report that they do it because they are bored (BROOKS, 2016). Perhaps, it is the time to revise how college students are being taught and to encourage alternative ways to handle mobile technology use in order to better engage students in classroom activities.

\section{References}

ALSON, J. N. \& MISAGAL, L. V. (2016). Smart Phones Usage Among College. IMPACT: International Journal of Research in Engineering \& Technology, Vol. 4, Issue 3, p. 63-70.

BARNES, K.; MARATEO, R. C.; \& FERRIS, S. P. (2007). Teaching and Learning with the Net Generation. Innovate: Journal of Online Education, Vol. 3: Issue 4, Article 1. Retrieved from http://nsuworks.nova.edu/innovate/vol3/iss4/1

BAUMAN, Z. Liquid Modernity. Polity Press, 2000.

BROOKS, D. C. (2016). ECAR Study of Undergraduate Students and Information Technology. EDUCAUSE Center for Analysis and Research report. Louisville, CO: ECAR, October 2018.

CRESWELL. J. (2003). Research design: Qualitative, quantitative, and mixed methods approaches (2nd ed.). Thousand Oaks, CA: Sage Publications, Inc.

GEE, J. P. (2011). An introduction to discourse analysis: theory and method (3rd ed.). Routledge, New York, NY.

GINGERICH, A. C. H. \& LINEWEAVER, T. T. F-atal Distraction: The Impact of In-Class Media Multitasking on Students' Classroom Learning. In HARNISH, R. J., BRIDGES, K. R., SATTLER, D. N., M. L. SIGNORELLA, M. L., MUNSON, M. (Eds.) (2018). The Use of Technology in Teaching and Learning. Retrieved from http://teachpsych.org/ebooks/

JONES, Steve. (2002). The Internet Goes to College: How Students Are Living in the Future with Today's Technology. Pew Internet and American Life Project, Washington, DC.

KAISER FAMILY FOUNDATION. (2005). Generation M2: Media in the Lives of 8- to 18-Year-Olds. Retrieved from http://www.kff.org/other/event/generation

KHALAFON, S. (2014). The rise of the mobile addict. Flurry Analytics, April 22, 2014.Retrieved from: http://flurrymobile.tumblr.com/post/115191945655/the-rise-of-the-mobile-addict

KUZNEKOFF, J. H. \& TITSWORTH, S. (2013). The Impact of Mobile Phone Usage on Student Learning. Journal Communication Education, Vol. 62, Issue 3, p. 233-252. Retrieved from http://dx.doi.org/10.1080/03634523.2013.767917

MARTINS, C. (2015). Digital Generation, Net generation, millennials, Y generation: reflecting about the relationship between youth and digital technologies. Diálogo, Vol. 29, Aug. 2015. Retrieved from http://www.revistas.unilsalle.edu.br/index.php/Dialogo

NICOLACI-DA-COSTA, A. M. (2004). Psychological Impacts of the Use of Cell Phones: An Exploratory Study of Brazilian Youth. Psicologia: Teoria e Pesquisa, Vol. 20 Issue 2, p. 165-174. Retrieved from http://www.scielo.br/scielo.php?pid=S0102-37722004000200009\&script=sci_arttext\&tlng=pt (2005). Virtual Sociability: Separating the tares from the wheat. Psicologia \& Sociedade, Vol. 17, Issue 2, p. 50-57. Retrieved from http://www.scielo.br/pdf/psoc/v17n2/27044.pdf

OBLINGER, D., \& .OBLINGER, J. Chapter 2: Is It Age or IT: First Steps Toward Understanding the Net Generation. In OBLINGER, D., \& .OBLINGER, J. (Eds.) (2005). Educating the Net Generation. Washington, D.C.: EDUCAUSE. Retrieved from http://www.ict-21.ch/com-ict/IMG/pdf/Educating-the-Net-Generation-Pages-1-5-de-pub7101.pdf

PAMPANELLI, G. A. (2004). The telephone evolution and a new form of sociability: The Flash Mob.Razón y Palabra, Vol. 41. Retrieved from http://www.razonypalabra.org.mx/anteriores/n41/gazevedo.html

POLL, H. (2015). Pearson Student Mobile Device Survey 2015. National Report: College Students. June, 2015. Retrieved from http://www.pearsoned.com/wp-content/uploads/2015-Pearson-Student-Mobile-Device-Survey-College.pdf

ROSSING, J. P., MILLER, W. M., CECIL, A. K. \& STAMPER, S. E. (2012). iLearning: The future of higher education? Student perceptions on learning with mobile tablets. Journal of the Scholarship of Teaching and Learning, Vol. 12, Issue. 2 , p. $1-26$.

SILVA, S. R. (2007). "Can' t live without a cell phone": Sociability, Consumerism, Corporality and new urban cultural practices. XXX Congresso Brasileiro de Ciências da Comunicação, Santos. Retrieved from http://www.intercom.org.br/papers/nacionais/2007/resumos/R1736-1.pdf

TAPSCOTT, Don. Growing Up Digital: The Rise of the Net Generation. (1998). New York: McGraw-Hill Education Professional. 